\title{
PHYSIOLOGICAL RESPONSES OF THE BROWN MUSSEL Perna perna (MOLLUSCA, BIVALVIA) EXPOSED TO THE ANIONIC SURFACTANT LINEAR ALKYLBENZENE SULPHONATE (LAS)
}

\section{RESPOSTAS FISIOLÓGICAS DE MEXILHÃO Perna perna (MOLLUSCA, BIVALVIA) EXPOSTO AO SURFACTANTE ANIÔNICO ALQUILBENZENO SULFONATO LINEAR (LAS)}

\section{Marina Freitas Stefanoni, Denis Moledo de Souza Abessa}

${ }^{1,2}$ Universidade Estadual Paulista Júlio de Mesquita Filho, Campus do Litoral Paulista. Praça Infante Dom Henrique s/n, Parque Bitaru. 11330-900 - São Vicente, SP. Telefone: (13) 35699419 Fax: (13) 35699401, e-mail: stefanoni@gmail.com

\begin{abstract}
The effects of the Linear Alkylbenzene Sulphonate (LAS) were evaluated on the mussel Perna perna, using physiological and genotoxic biomarkers. The Micronuclei (MN) assay was used to estimate effects at nuclear level, whereas the physiological effects were evaluated by measuring the oxygen consumption and ammonia excretion rates. Significant effects were observed for the MN assay and the ammonia excretion rate, even in low concentrations. The oxygen consumption was not affected in the tested concentrations. For MN and ammonia excretion, the animals exposed to intermediate concentrations were not affected, but responded to the higher concentrations, indicating the existence of compensatory mechanisms at physiological level. However, parallel to this study other authors indicate the presence of progressive effects at the cellular level, suggesting that the organisms are not capable to recover of such increasing effects. Additionally, the results show that the levels of LAS observed for Brazilian coastal waters may chronically affect the biota. Keywords: Ecotoxicology. Biomarkers. Detergent. Effect. Marine pollution. Mussel.
\end{abstract}

\section{RESUMO}

Os efeitos do Alquilbenzeno Sulfonato de Sódio Linear sobre o mexilhão Perna perna foram avaliados por meio do uso de biomarcadores genotóxicos e fisiológicos. O ensaio da taxa de micronúcleos $(\mathrm{MN})$ foi conduzido para estimar o efeito ao nível nuclear, enquanto os efeitos fisiológicos foram avaliados através da medição da taxa de consumo de oxigênio e de excreção de amônia. Efeitos significativos foram observados para o ensaio do $\mathrm{MN}$ e para a taxa de excreção de amônia, mesmo em baixas concentrações. O consumo do oxigênio não foi afetado pelas 
concentrações dos ensaios. Para MN e excreção de amônia, os animais expostos às concentrações intermediárias não foram afetados, mas responderam às maiores concentrações, sugerindo a existência de mecanismos compensatórios em nível fisiológico. Contudo, paralelamente ao presente estudo, outros autores demonstraram haver efeitos progressivos em nível celular, sugerindo que os organismos não conseguem se recuperar dos efeitos crescentes da exposição. Os resultados ainda mostram que níveis de LAS presentes na costa brasileira podem afetar cronicamente a biota.

Palavras-chave: Ecotoxicologia. Biomarcadores. Detergente. Efeito. Poluição marinha. Mexilhão.

\section{INTRODUCTION}

The detergents are often present in industrial and domestic effluents, due to their multiple uses; such compounds are used worldwide as cleaning agents, are employed in the production of oil and the textile industry; are applied in mineral extraction and exploration, and frequently are used as dispersants during oil spills (LEWIS, 1991). These substances have surfactant properties, i.e. the molecules present a polar and a non polar regions, which allows them to reduce the superficial tension of a solution, to concentrate in surfaces and to form ions aggregates and micelles (ABEL, 1974).

In the last 25 years, the anionic surfactant Linear Alkylbenzene Sulphonate (LAS) has been the most used in the composition of domestic detergents (LARSON and WOLTERING, 1995). This compound started to be produced during the 1960's decade, substituting the Alquilbeneze sulfonates (ABS) (HOLMAN and MACEK, 1980). The LAS is nowadays widely spread in many different aquatic environments, where it has a significant pollutant potential. Since the 1970's decade, investigations on the toxic effects of the LAS have been conducted with aquatic organisms, as fish (SWEDMARK et al., 1971; BARBIERI et al., 2002), crustaceans (SWEDMARK et al., 1971; LEWIS and SUPRENANT, 1983; SINGH et al., 2002) and mollusks (SWEDMARK et al., 1971; MARIN et al., 1994; DA ROS et al., 1995; HANSEN et al., 1997), especially in Europe and North America.

The main effects already appointed as a result from the exposure of aquatic organisms to anionic detergents are cellular, histological and physiological damages, which comprise alterations in the gill tissues (SWEDMARK et al., 1971; ABEL, 1974; SUPRIYONO et al., 1998), lysossomal disturbances and enzymatic inhibition or stimulation (DREWA, 1988; DA ROS et al., 1995), growth reduction (HANSEN et al., 1997) and alteration of the cardiac activity (SWEDMARK et al., 1971).

The purpose of this study was to evaluate the LAS effects on the brown mussel Perna perna (LINNAEUS, 1758), resorting to the use of the biomarkers at different levels of biological organization, in order to contribute to the comprehension of its toxic mode of action and to the management of the LAS environmental levels. To achieve that, the Micronuclei assay (MN) was used, together with the evaluation of the oxygen consumption (OCR) and ammonia excretion (AER) rates.

\section{MATERIALS AND METHODS}

Adult healthy individuals of $P$. perna $(41.2$ - $77.3 \mathrm{~mm}$ shell length) were collected from a mussel farm, located at Cocanha Beach, Caraguatatuba, São Paulo' State North Shore, in the Brazil. According to the State Environmental Agency, this site is considered clean and its waters present good quality (CETESB, 2007). After collection, the animals were acclimated to laboratory conditions for 24 hours, in tanks containing filtered seawater and maintained under intense and 
continuous aeration, constant temperature $\left(25 \pm 2{ }^{\circ} \mathrm{C}\right)$ and natural conditions of light.

The LAS test-solutions were prepared by diluting a stock solution (50 mg.L $\mathrm{L}^{-1} \mathrm{LAS}$; Merck, with $99 \%$ purity) in filtered sea water. The following LAS concentrations were prepared for the experiments: $0.50 ; 0.25 ; 0.13 ; 0.06$ and $0.03 \mathrm{mg} . \mathrm{L}^{-1}$; but for the AER and OCR experiments, a 1.0 $\mathrm{mg} . \mathrm{L}^{-1}$ LAS concentration was additionally prepared. Filtered (100 $\mu \mathrm{m}$ acetate membrane) sea water was used as control.

The experiment consisted in exposing the animals for $24 \mathrm{~h}$ to the LAS dilutions, and observed the sub-lethal effects. The physical-chemical characteristics of the different tested solutions were monitored in all the experiments.

For the Micronuclei (MN) assay, the method described by Fossi et al. (2000) was followed, using the blood of ten animals of each treatment. The rate of micronuclei in blood cells was obtained by counting 2000 cells under microscope and calculating the number of MN in 1000 cells. The frequency of MN was calculated for each concentration and the comparison to the control was made by analysis of variance (ANOVA) followed by the Dunnett test (ZAR, 1984).

For the oxygen consumption and ammonia excretion experiments, three organisms were used in each tested dilution. After $24 \mathrm{~h}$ exposure, the animals were transferred to sealed individual respirometers $(0.5 \mathrm{~L})$, containing filtered seawater which concentrations of dissolved oxygen (mg. $\left.\mathrm{L}^{-1}\right)$ and ammonia (mg.L $\mathrm{L}^{-1}$ ) were previously measured. The animals were kept for one hour in the respirometers, then the dissolved oxygen and ammonia levels were measured again by using an oxymeter (DIGIMED, model DM-04, with precision of 0.01 unities when reading $\mathrm{mg} . \mathrm{L}^{-1}$ ) and a conductivity meter (Lutron, model 206, precision of 0.01 unities) coupled to an electrode for ammonia readings, respectively. The differences between final and initial values gave the oxygen consumption and ammonia excretion rates, and they were divided by the wet weights of the respective animals. The OCR data were analyzed by ANOVA followed by the Dunnett test, whereas the results of the AER experiment were tested by the non-parametric Mann-Whitney test.

\section{RESULTS AND DISCUSSION}

In all the experiments, the physical-chemical characteristics of the tested dilutions showed very small variations: salinities ranged between 33 and 35\%, temperatures ranged from 23 to $25^{\circ} \mathrm{C}$ and $\mathrm{pH}$ ranged between 7.60 and 8.08 .

The MN frequency, the presence of micronuclei was significantly higher than the control $(\mathrm{p}<0.05)$ for the organisms exposed to 0.5 and $0.03 \mathrm{mg} \mathrm{l}^{-1} \mathrm{LAS}$ (Fig. 1). Although the effects have been rapid, the animals exposed to intermediate concentrations appeared to recover, being affected in the higher concentrations.

The AER assay presented significant differences $(p<0.05)$ between the animals exposed to 0.03 and $0.5 \mathrm{mg} . \mathrm{L}^{-1}$ and the control (Fig. 2). The dose-response curve showed a tendency of lower ammonia excretion rates at smaller, and higher concentrations and rates at the intermediary concentrations $\left(0.12\right.$ and $\left.0.25 \mathrm{mg} . \mathrm{L}^{-1}\right)$.

For the OCR assay, no significant differences were observed (Fig. 3). 


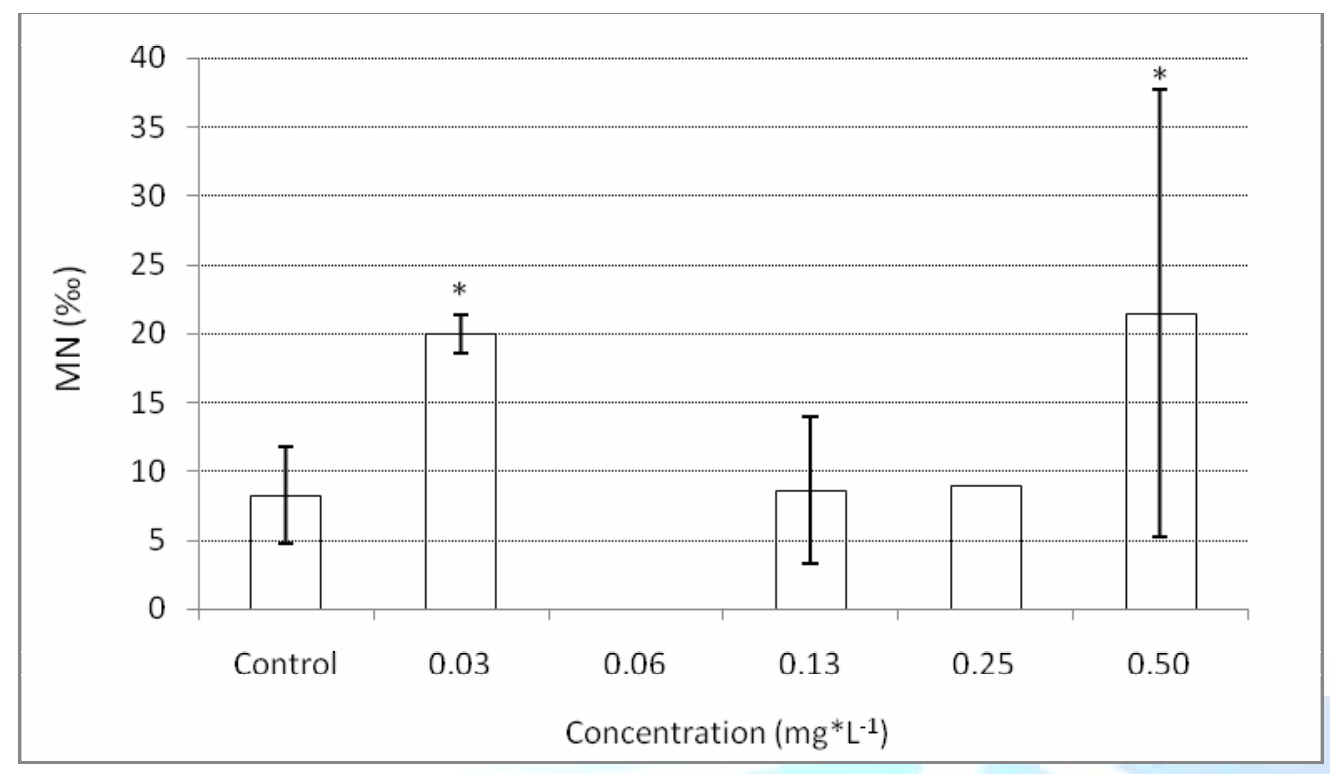

Figure 1. Mean MN rates ((\%)) in haemocytes lysosomes of the mussel $P$. perna (Error bars indicate standard deviations and * indicates significant differences, $\mathrm{p} \leq 0.05$ ).

The results of the MN and AER assays exhibited a similar trend, which consisted in effects at the lower tested concentration and lacking of significant effects at intermediate LAS concentrations, thus the initial effects can be considered as a "warning effect". The AER response showed a significant decrease of the excretion rate of the animals exposed to the $0.03 \mathrm{mg} . \mathrm{L}^{-1} \mathrm{LAS}$, indicating a metabolic inhibition to avoid energetic losses during a continued exposure to the contaminant at low levels. Afterwards, the animals exposed to intermediary concentrations presented stimulation in their AER, suggesting that the metabolism was activated, to detoxify from the detergent and/or to heal damages in the cells and tissues. Finally, in the higher concentrations, the animals showed again a decreased AER, which normally occurs in stress situations, when the organism can not maintain a high energetic supply to the detoxification process, because the vital metabolic functions need to be preserved (SHUHONG et al., 2005). Similar patterns of physiological response in invertebrates exposed to contaminants were observed by other authors (DEPLEDGE and ANDERSEN, 1990; DEPLEDGE et al., 1995).

For the MN assay, results indicated higher rates only at 0.03 and $0.5 \mathrm{mg} . \mathrm{L}^{-1} \mathrm{LAS}$, suggesting also that the organisms possibly may activate mechanisms of DNA repair; however, in increasing concentrations such mechanisms become ineffective.

Regarding to the OCR, no differences were found among the control and the different tested concentrations; however, there was a tendency to occur a slight increase in the respiratory rate in low and intermediary concentrations, which could be related to metabolic alterations caused by the LAS or to a tentative of depurate the detergent and recover from its effects. Studies with fishes showed a similar pattern and found responses in the animals exposed to low LAS concentrations (BARBIERI et al., 2000; BARBIERI et al., 2002). Marin et al. (1994), in a study on the effects of LAS contaminated sediments on the mussel Mytilus galloprovincialis, observed a not significant increase in the respiratory rate of the exposed organism. 


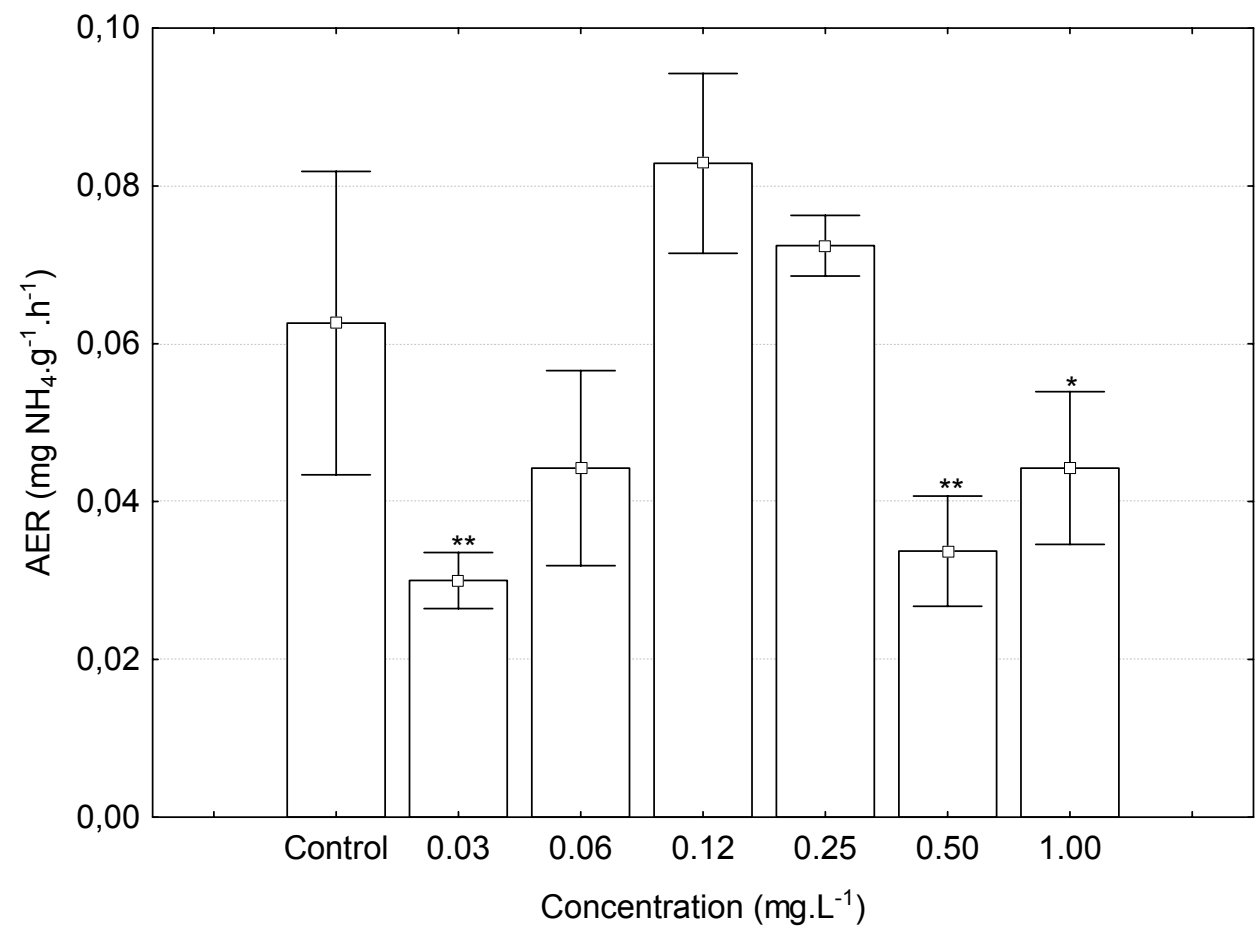

Figure 2. Ammonia excretion mean rates of mussels exposed to different LAS concentrations. Error bars indicate standard deviations (* shows significant differences for $\mathrm{p} \leq 0.05$ and $* *$ show significant differences for $\mathrm{p} \leq 0.01)$.

Depledge and Andersen (1990) and Depledge et al. (1995) mentioned the capability of marine organisms to compensate, temporarily or partially, the contaminants effects by physiological mechanisms. However, if the alterations in biochemical, cellular and histological levels keep growing or remain constant for longer periods, the animals frequently cannot maintain such compensatory mechanisms, and then the physiological effects become apparent. Such theory makes sense when the data obtained by Stefanoni and Abessa (2008) for the Neutral Red Retention Time (NRRT) assay, which were taken for the same organisms evaluated in the present study; such authors observer a progressive effect, from the lower to the higher concentration, and suggested that they were produced by a combination of physical interference of the LAS on the membranes, especially the lysosomal ones, the accumulation of xenobiotic in the lysosomes, and the oxidative stress produced during the depuration process, which causes lipoperoxidation.

Once lysosomes represent the main organelles responsible to remove toxic compounds from the citosol, their membranes are susceptible to the stress induced by xenobiotics, (MOORE, 1982, 1985). In many invertebrates, lysosomes play a key role in the process of mediating enzymes for the catabolism of endogenous and exogenous material, and in the regulation of the cellular homeostasis, by fagocitosis, digestion, depuration and excretion of xenobiotics (MOORE, 1985; VIARENGO et al., 1987; MCVEIGH at al., 2006). As contaminants accumulate in the lysosomes, alterations and damages in the lysosomal membranes may occur and cause a releasing of the digestive enzymes to the citosol, which would produce autolysis (MOORE, 1985; MCVEIGH et al., 2006). Also, due to the tens active properties of detergents, the biological membranes are main targets of such compounds, due to their ability to combine with themselves (BRAGADIN et al., 1996; CSERHÁTI et al., 2002). Moreover, as a result of the depuration process, free species of oxygen can be produced; consequently, alteration in the concentration of antioxidant enzymes may occur (DA ROS et al., 1995) producing lipoperoxidation and affecting the stability of the biological membranes (TORRES et al., 2002; GORINSTEIN et al., 2003). Several authors have shown that 
LAS exposure induces biochemical effects on aquatic organisms, from stimulation of acid phosphatases (JONSSON et al., 2009), soluble cholinesterases and activation of anti-oxidant systems (NUNES et al., 2006); Álvarez-Muñoz et al. (2007) observed increased levels of catalase, glutathione-S-transferase and phosphatases in fishes exposed to LAS, indicating occurrence of oxidative stress. Nunes et al. (2006) also observed the presence of thiobarbituric acid reactive substances (TBARS) which represent products of lipid peroxidation.

Therefore, the published papers could help us to explain the relationship between the measured responses at nuclear and physiological levels and those observed by Stefanoni and Abessa (2008) at cellular levels. The significant effects for MN and the tendency of inhibited AER among the mussels exposed to the higher LAS concentrations suggest that the animals have their metabolism altered due to damages in the gill cells and tissues, as described in the literature (ABEL, 1974; DREWA, 1988; CHEUNG and CHEUNG, 1995; HOFER et al., 1995; SUPRIYONO et al., 1998; SWEDMARK et al., 1973).

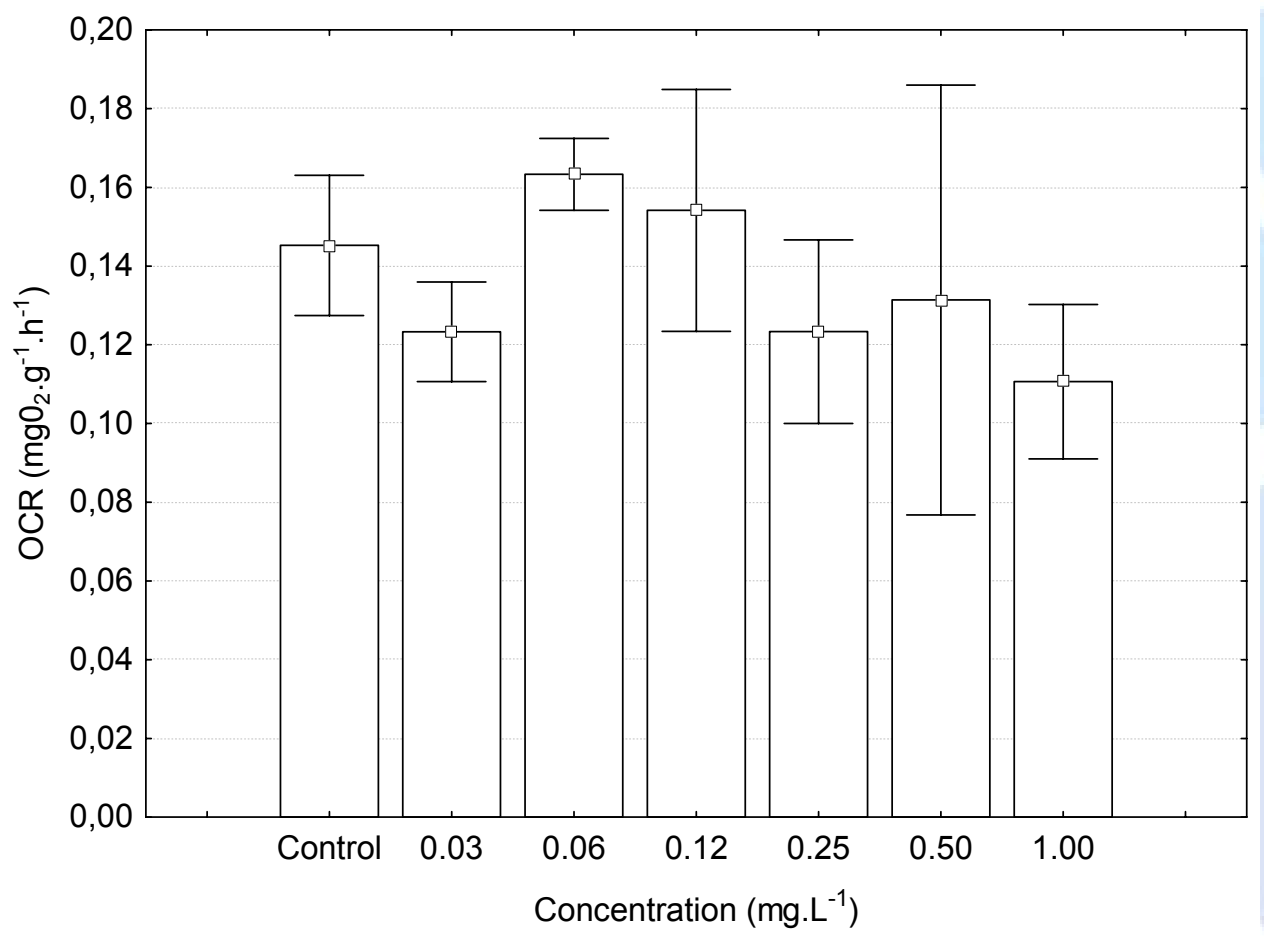

Figure 3. Oxygen consumption mean rates of mussels exposed to different LAS concentrations. Error bars indicate standard deviations.

In Brazil, detergents have not been considered main importance contaminants for the aquatic environment, despite their widespread and growing use in the country, and proved toxicity. However, the information about their toxic effects on the biological communities is still incipient, constituting an obstacle for the establishment of regulations and to the determination of maximum concentrations for the effluents discharged into the environment.

In the present study, significant LAS effects on mussels occurred in concentrations lower than those found by other authors (MASTROTI et al., 2001; STEFANONI and ABESSA, 2008) and are of main concern because the toxic levels were similar or below to the reported concentrations of LAS in estuarine and marine waters of São Paulo' State, which ranged between 0.03 and $2.08 \mathrm{mg} . \mathrm{L}^{-1}$ with exceptional values reaching $8.47 \mathrm{mg} . \mathrm{L}^{-1}$ (MASTROTI et al., 1998). Thus, the current levels of LAS in the environment may be enough to produce toxic effects on the biota. More attention must be given to the presence of surfactants in the environment, especially in marine 
and estuarine waters, once these compounds are toxic and widely discharged into the coastal waters. The results suggest that maximum permitted concentration of LAS in salt waters should be at least lower than $0.03 \mathrm{mg} . \mathrm{L}^{-1}$, in order to avoid sub-lethal effects and long-term ecological disturbances. Further studies are necessary, performed with other species in order to establish legal standards for LAS in marine and estuarine Brazilian waters.

\section{ACKNOWLEDGEMENTS}

We would like to thank FAPESP for the first author's scholarship grant (Process \#04/123269), and Dr. Eduinetty Ceci de Sousa, Dr. José Augusto David, Dr. Camilo Dias Seabra Pereira and Biol. Robson Seriani for the personal help.

\section{REFERENCES}

ABEL, P.D. Toxicity of synthetic detergents to fish and aquatic invertebrates. Journal of Fish Biology, v. 6, p. 279-298. 1974.

ÁLVAREZ-MUÑOZ, D.; LARA-MARTÍN, P.A.; BLASCO, J.; GÓMEZ-PARRA, A.; GONZÁLEZ-MAZO, E. Presence, biotransformation and effects of sulfophenylcarboxylic acids in the benthic fish Solea senegalensis. Environment International, v. 33, n. 4, p. 565-570. 2007.

BARBIERI, E., PHAN, N.G.; GOMES, V. Efeito do LAS-C12, Dodecil Benzeno Sulfonato de Sódio Linear, na taxa metabólica e na capacidade de natação de Cyprinus carpio. Ecotoxicology and Environmental Restoration, v. 3, n. 2, p. 69-75. 2000.

BARBIERI, E., OLIVEIRA, I.R.; SERRALHEIRO, P.C.S. The use of metabolism to evaluate the toxicity of dodecil benzen sodium sulfonate (LAS-C12) on the Mugil platanus (mullet) according to the temperature and salinity. Journal of Experimental Marine Biology and Ecology, v. 277, p. 109-127. 2002.

BRAGADIN, M., PERIN, G., RACCANELLI, S.; MANENTE, S. The accumulation in lysosomes of the anionic detergent linear alkylbenzene sulfonate. Environmental Toxicology And Chemistry, v. 15, n. 10, p. 1749-1751. 1996.

CETESB. 2007. Relatório de qualidade das águas litorâneas do estado de São Paulo: balneabilidade das praias 2006. Série Relatórios / Secretaria de Estado do Meio Ambiente, São Paulo, CETESB. 2007. $365 \mathrm{p}$.

CHEUNG, S.G.; CHEUNG, R.Y.H. Effects of heavy metals on oxygen consumption and ammonia excretion in green-lipped mussels (Perna viridis). Marine Pollution Bulletin, v. 31, n. 4-12, p. 381-386. 1995.

CSERHÁTI, T., FORGÁCS, E.; OROS, G. Biological activity and environmental impact of anionic surfactants. Environment International, v. 28, p. 337-348. 2002. 
DA ROS, L.; NASCI, C.; CAMPESAN, G.; SARTORELLO, P.; STOCCO, G.; MENETTO, A. Effects of linear alkylbenzene sulphonate (LAS) and cadmium in the digestive gland of mussel, Mytilus sp. Marine Environmental Research, v. 39, p. 321-324. 1995.

DEPLEDGE, M.H.; ANDERSEN, B.B. A computer - aided physiological monitoring system for continuos, long-term recording of cardiac activity in selected invertebrates. Comparative Biochemistry and Physiology, v. 96, n. A 4, p. 473-477. 1990.

DEPLEDGE, M.H.; AAGAARD, A.; GYÖRKÖS, P. Assessment of trace metal toxicity using molecular, physiological and behavioural biomarkers. Marine Pollution Bulletin, v. 31, p. 19-27. 1995.

DREWA, G. The effect of detergent ABS on shrimp Crangon crangon. Polskie archiwum hydrobiologii, v. 35, n.1, p. 97-108. 1988.

FOSSI, M.C.; CASINI, S.; SAVELLI, C.; CORBELLI, C.; FRANCHI, E.; MATTEI, N.; SANCHEZ-HERNANDEZ, J.C.; CORSI, I.; BAMBER, S.; DEPLEDGE, M.H. Biomarker responses at different levels of biological organisation in crabs (Carcinus aestuarii) experimentally exposed to benzo(a)pyrene. Chemosphere, v. 40, p. 861-874. 2000.

GORINSTEIN, S.; MONCHEVA, S.; KATRICH, E.; TOLEDO, F.; ARANCIBIA, P.; GOSHEV, I.; TRAKHTEHBERG, S. Antioxidants in the black mussel (Mytilus galloprovincialis) as an indicator of black sea coastal pollution. Marine Pollution Bulletin, v. 46, p. 1317-1325. 2003.

HANSEN, B.; FOTEL, F. L.; JENSEN, N. J.; WITTRUP L. Physiological effects of the detergent linear alkylbenzene sulphonate on blue mussel larvae (Mytilus edulis) in laboratory and mesocosm experiments. Marine Biology, v. 128, p. 627-637. 1997.

HOFER, R.; JENEY, S.; FRANZ, B. Chronic effects of linear alkylbenzene sulfonate (LAS) and ammonia on rainbow trout (Oncorhynchus mykiss) fry at water criteria limits. Water Research, v. 29, n. 12, p. 2725-2729. 1995.

HOLMAN, W.F.; MACEK, K.J. An aquatic safety assessment of linear alkylbenzene sulfonate (LAS): chronic effects on fathead minnows. Transaction of the American Fisheries Society, v. 109, p. 122-131. 1980.

JONSSON, C.M.; PARAIBA, L.C.; AOYAMA, H. Metals and linear alkylbenzene sulphonate as inhibitors of the algae Pseudokirchneriella subcapitata acid phosphatase activity. Ecotoxicology, v. 18, p. 610-619. 2009.

LARSON, R.J.; WOLTERING, D.M. Linear alkylbenzene sulfonate (LAS). In: RAND, G. M. (Ed.). Fundamentals of Aquatic Toxicology: effects, environmental fate and risk assessment. Washington D.C., Taylor \& Francis. 1995. p. 859-882.

LEWIS, M.A.; SUPRENANT, D. Comparative acute toxicities of surfactants to aquatic invertebrates. Ecotoxicology and Environmental Safety, v. 7, p. 313-322. 1983.

LEWIS, M. A. Chronic and sublethal toxicities of surfactants to aquatic animals: a review and risk assessment. Water Research, v.25, n. 1, p. 101-113. 1991. 
MARIN, M.G.; PIVOTTI, L.; CAMPESAN, G.; TURCHETTO, M.; TALLANDINI, L. Effects and fate of sediment-sorbed linear alkylbenzene sulfonate (LAS) on the bivalve mollusc Mytilus galloprovincialis. Water Research, v. 28, n. 1, p. 85-90. 1994.

MASTROTI, R.R.; SOUSA, E.C.P.M.; ABESSA, D.M.S.; SASS, V. Avaliação preliminar da biodegradabilidade de tensoativos aniônicos em água do mar. Revista Brasileira de Oceanografia, v. 46, n. 2, p. 187-193. 1998.

MASTROTI, R.R.; SOUSA, E.C.P.M.; ABESSA, D.M.S. Toxicidade de tensoativos aniônicos sobre embriões de ouriço do mar Lytechinus variegatus. In: MORAES, R.; CRAPEZ, M.; PFEIFFER, W.; FARINA, M.; BAINY, A.C.D.; TEIXEIRA, V. (Eds.). Efeitos de Poluentes sobre Organismos Marinhos. São Paulo, Arte \& Ciência Villipress. 2001. p. 207-216.

MCVEIGH, A., MOORE, M., ALLEN, J.I.; DYKE, P. Lysosomal responses to nutritional and contaminant stress in mussel hepatopancreatic digestive cells: A modelling study. Marine Environmental Research, v. 62 (Supplement 1), p. 433-438. 2006.

MOORE, M.N. Lysosomes and environmental stress. Marine Pollution Bulletin, v. 13, n. 2, p. 4243. 1982.

MOORE, M.N. Cellular responses to pollutants. Marine Pollution Bulletin, v. 16, p. 134-139. 1985.

NUNES, B.; CARVALHO, F.; GUILHERMINO, L. Effects of widely used pharmaceuticals and a detergent on oxidative stress biomarkers of the crustacean Artemia parthenogenetica.

Chemosphere, v. 62, n.4, p. 581-594. 2006.

SHUHONG, W.; HUASHENG, H.; XINHONG, W. Bioenergetic responses in green lipped mussels (Perna viridis) as indicators of pollution stress in Xiamen coastal waters, China. Marine Pollution Bulletin, v. 51, n. 8-12, p. 738-743. 2005.

SINGH, R.P.; GUPTA, N.; SINGH, S.; SINGH, A.; SUMAN, R.; ANNIE, K. Toxicity of ionic and nonionic surfactants to six macrobes found in Agra, Índia. Bulletin of Environmental Contamination and Toxicology, v. 69, p. 265-270. 2002.

SUPRIYONO, E.; TAKASHIMA, F.; STRUSSMANN, C.A. Toxicity of linear alkylbenzene sulphonate (LAS) to juvenile kuruma shrimp, Penaeus japonicus: a histopathological study on acute and sub-chronic levels. Journal of Tokyo University of Fisheries, v. 85, n. 1, p. 1-10. 1998.

STEFANONI M.F.; ABESSA D.M.S. Lysossomal membrane stability of the brown mussel Perna perna (Linnaeus) (Mollusca, Bivalvia) exposed to the anionic surfactant linear alkylbenzene sulphonate (LAS). Pan-American J Aquat Sci, v.3, n.1, p.6-9, 2008.

SWEDMARK, M.; BRAATEN, B.; EMANUELSSON, E.; GRANMO, A. Biological effects of surface active agents on marine animals. Marine Biology, v. 9, p. 183-201. 1971.

SWEDMARK, M.; GRANMO, A.; KOLLBERG, S. Effects of the oil dispersant and oil emulsions on marine animals. Water Research, v. 7, p. 1649-1672. 1973. 
TORRES, M.A.; TESTA, C.P.; GÁSPARI, C.; MASUTTI, M.B.; PANITZ, C.M.; CURIPEDROSA, R.; ALMEIDA, E.A.; DI MASCIO, P.; WILHELM FILHO, D. Oxidative stress in the mussel Mytella guyanensis from polluted mangroves on Santa Catarina island, Brazil. Marine Pollution Bulletin, v. 44, p. 923-932, 2002.

VIARENGO, A.; MOORE, M.N.; MANCINELLI, G.; MAZZUCOTELLI, A.; PIPE, R.K.; FARRAR, S.V. Metallothineins and lysosomes in metal toxicity and accumulation in marine mussels: effect of cadmium in the presence and absence of phenathrene. Marine Biology, v. 94, p. 251-257. 1987.

ZAR, J.H. Biostatistical analysis. New Jersey, Prentice Hall, 718 p. 1984. 